\title{
Analysis on the International Trends in Safe Management of Very Low Level Waste Based upon Graded Approach and Their Implications
}

\section{차등접근법에 근거한 극저준위폐기물의 안전관리 국제동향 및 시사점에 대한 고찰}

\author{
Jae Hak Cheong1) \\ Korea Institute of Nuclear Safety, 34 Gwahak-ro, Yuseong-gu, Daejeon
}

정재학1)

한국원자력안전기술원, 대전광역시 유성구 과학로 34

(Received September 16, 2010 / Revised December 28, 2010 / Approved January 06, 2011)

\begin{abstract}
Recently, International Atomic Energy Agency and major leading countries in radioactive waste management tend to subdivide the categories of radioactive waste based upon risk-graded approach. In this context, the category of very low level waste has been newly introduced, or optimized management options for this kind of waste have been pursued in many countries. The application of engineered surface landfill type facilities dedicated to dispose of very low level waste has been gradually expanded, and it was analyzed that their design concept of isolation has been much advanced than those of the old fashioned surface trench-type disposal facilities for low and intermediate level waste, which were usually constructed in 1960's. In addition, the management options for very low level waste in major leading countries are varied depending upon and interfaced with the affecting factors such as: national framework for clearance, legal and practical availability of low and intermediate level waste repository and/or non-nuclear waste landfill, public acceptance toward alternative waste management options, and so forth. In this regard, it was concluded that optimized long-term management options for very low level waste in Korea should be also established in a timely manner through comprehensive review and discussions, in preparation of decommissioning of large nuclear facilities in the future, and be implemented in a systematic manner under the framework of national policy and management plan for radioactive waste management.
\end{abstract}

Key words : Very low-level radioactive waste, Graded Approach, Landfill disposal, International trend, Safe management, Implications

요 약

최근 국제원자력기구와 방사성폐기물 분야 주요 선도국들은 리스크 차등접근법에 따라 방사성폐기물

1) Corresponding Author. E-mail : radwaste@kins.re.kr 
의 분류기준을 세분화하고 있는 추세이며, 이러한 맥락에서 극저준위폐기물을 새로운 방사성폐기물 범주 로서 신설하거나 이에 대한 별도의 최적 관리방안을 모색하고 있다. 국제적으로 운영 사례가 점차 증가되 고 있는 주요 국가의 극저준위폐기물 전용 공학적 표층매립형 처분시설들은 방사성핵종의 격리 및 지연 성능 측면에서 1960년대 주로 건설된 천층 트렌치형 중 - 저준위폐기물 처분시설 보다 개선된 것으로 분 석되었다. 또한 주요 선도국들의 극저준위폐기물 관리방안은 규제해제 제도, 중 - 저준위폐기물 처분시설 및 비원자력 폐기물매립장의 활용 가능성, 사회수용성 둥에 따라 차이가 있는 것으로 나타났다. 이와 관 련하여, 국내에서도 향후 대형 원자력시설의 해체에 대비하여 극저준위폐기물의 최적 관리방안에 관한 종합적인 검토와 논의를 통해 리스크 차등접근법에 따른 최적화된 관리방안을 사전에 수립하고, 이를 국 가 방사성폐기물 관리정책 및 관리계획의 틀 내에서 체계적으로 시행할 필요가 있다.

중심단어 : 극저준위폐기물, 리스크차등 접근법, 표층매립, 국제동향, 안전관리, 시사점

\section{I. 서 론}

원자력 안전규제에서 결정론적(deterministic)이고 처방적 (prescriptive)인 요건에 기반한 전통적인 방법의 한계를 극복 하고 안전규제의 효과성과 효율성을 제고하기 위한 목적으로, 리스크(risk) 정보를 활용하여 궁극적으로 성능(performance) 목표에 기반 한 안전규제 방법이 1990 년대부터 활발하게 논의 되고 있으며 현재 국내외에서 실제로 적용되고 있다. 한편, 차 등접근법(graded approach)이란 적용되는 규제조치와 조건의 강도를 규제대상의 특성과 리스크 수준에 상응하도록 하는 과 정(process)이나 방법(method)으로 해석될 수 있으며, 리스크 정보를 활용한 차등접근법의 적용은 최근 국제원자력기구 (International Atomic Energy Agency, IAEA)의 기본안전원칙 에도 의무사항으로 서술되어 있다[1].

차등접근법은 방사성폐기물 안전 분야에서도 처분전관리, 처분, 해체 둥 다양한 분야에서 광범위하게 적용되고 있으며, 특히 최근에는 방사성폐기물의 분류기준 및 관리방안 최적화 에 리스크 차등접근법의 적용사례가 다수 보고되고 있다[2]. 이러한 맥락에서 일반적인 방사성폐기물에 비해 방사성핵종 의 함유량이 낮고 특히 원자력시설 해체폐기물의 대부분을 차 지하는 극저준위폐기물의 최적 관리방안으로서 규제해제 (clearance) 및 처분(disposal)에 관한 논의가 국제적으로 활발 하게 이루어지고 있다[3,41. 또한, 최근 IAEA는 잠재적인 리스 크와 최적 장기관리 방안에 근거한 차등접근법에 따라 방사성 폐기물 분류기준을 개정하면서 극저준위폐기물을 새로운 방 사성폐기물 범주로 분류하였으며, 다수의 국가들은 극저준위 폐기물을 법적으로 별도의 방사성폐기물 범주로 구분하고 전 용 처분시설을 운영하는 둥 최적관리방안을 모색하고 있는 것 으로 알려져 있다[5,6].
국내 원자력관계법령에서는 극저준위폐기물을 별도로 정의 하지 않고 있으나, 처분제한치(연간 개인선량 $0.01 \mathrm{mSv}$, 연간 집단선량 1 person-Sv) 미만의 방사성폐기물에 대해서는 원 자력법에 따라 허가된 방사성폐기물 처분시설에 처분하지 않 고 원자력관계사업자가 매립, 소각 또는 재활용 등의 방법으 로 자체처분할 수 있도록 허용하고 있다(그림 1 참조). 최근 일 부 국내 연구자들에 의해 리스크 차둥접근법에 따른 방사성페 기물 관리방안의 최적화 개념 및 관련 해외사례 등이 부분적 으로 소개된 바 있으나, 아직까지 처분제한치를 다소 상회하 는 극저준위폐기물의 관리방안 최적화를 위한 구체적인 논의 는 이루어지지 못하고 있다 $[7,8]$. 그러나 국내에서도 원자력시 설의 운영 및 부분해체 과정에서 처분제한치 미만의 극저준위 폐기물이 이미 상당량 발생되고 있으며, 향후 발전용원자로 등 대형 원자력시설의 해체가 시작되면 운영단게 보다 훨씬 더 많은 양의 극저준위폐기물이 단기간에 집중적으로 발생될 것이다[9,10]. 따라서 극저준위폐기물의 최적 장기관리 체계를

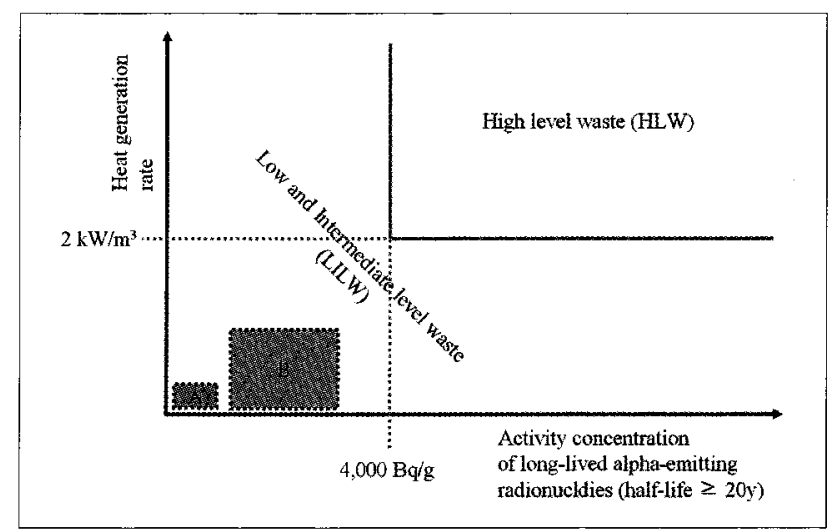

Fig. 1. Present classification system of radioactive waste in Korea under the Atomic Energy Act, along with typical waste streams to be released from regulatory control based upon the clearance provision(area $A$ ) and to be disposed of in the Wolsong LILW Disposal Center(area B). 
사전에 구축하지 못할 경우, 방사성폐기물 안전관리의 지속가 능성 확보에 부담으로 작용할 수 있고 또한 잠제적인 주요 안 전현안으로 대두될 가능성도 배제할 수 없다.

이와 관련하여 이 논문에서는 규제해제 제도 시행체계와 아 직까지 국내에서 심층적으로 논의된 바 없는 극저준위폐기물 전용 처분시설 운영현황을 중심으로 주오 국가들의 극저준위 페기물 장기관리 체계와 최근 현황을 조사 - 분석하였으며, 향 후 극저준위폐기물 안전관리와 관련하여 국내에서 고려되어 야 할 시사점을 함께 제시하였다.

\section{II. 극저준위폐기물의 안전관리 국제동향}

\section{가. 국제원자력기구}

2010년 IAEA는 방사정계기물 분류에 관한 안전지침 개정 본을 발간하였다 [5]. 개정된 안전지침에서 IAEA는 방사셩폐 기물을 반감기와 방사능 함유량에 따라 고준위폐기물(High Level Waste, HLW), 중준위폐기물(Intermediate Level Waste, ILW), 저준위폐기물(Low Level waste, LLW), 극저준 위폐기물(Very Low Level Waste, VLLW), 극단수명폐기물 (Very Short-Lived waste, VSLW) 및 규제해제폐기물(Exempt Waste, $\mathrm{EW}$ )의 6가지 범주로 분류하고, 각각의 폐기물에 대 한 전형적인 처분방식을 함께 제시하였다(그림 2 참조).

개정된 안전지침에서 특이할 만한 사항은 방사성폐기물 분 류를 위한 방사능준위를 정랑적으로 제시하지 않고 개녈 처 분장의 안전성평가 결과에 근거하어 구체화하도록 권고하고 있다는 점, 방사성폐기물의 처분관점에서 방사성핵중을 "단 수명” 으로 분류하는 기준을 반감기 30년으로 제안하고 일반 적으로 "저장붕괴” 의 대상이 되는 "극단수명" 을 반감기 수백 일 이하로 제안하고 있다는 점, VLLW의 경우 공학적 포층매 립형 처분시설(Engineered surface landfill type facilities)에

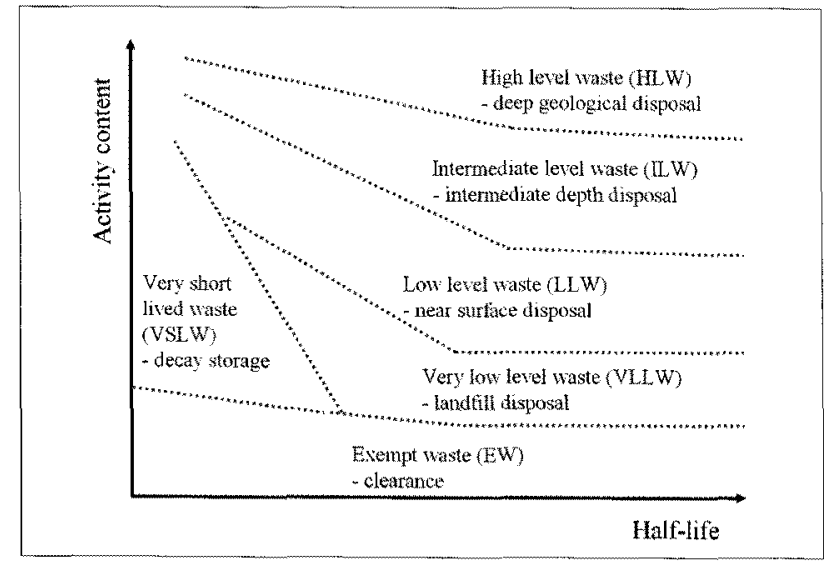

Fig. 2. International Atomic Energy Agency's classification system of radioactive waste[5].
처분하는 것으로 적절한 수준의 안전성을 확보할 수 있다는 입장을 밝히고 있다는 점이다. 이번에 개정된 표준 분류체계 는 기존의 분류체계에 비하여, 잠재적인 위험도와 적절한 최 종 관리방안(처분)에 근거하여 방사성페기물을 세분화하는 등 리스크 차등접근법에 충실한 것으로 평가할 수 있다.

한현, IAEA는 2004년 VLLW의 규제해제에 관한 안전기준 을 안전지침으로 발간한 바 있대11]. 이 안전치침에서는 대 먕 물질의 규제해제를 위한 방사선량기준으로 개인의 연간 유효선량 $0.01 \mathrm{mSv} / \mathrm{y}$ 및 저확률 사건에 대한 개인 유효선량 기준 $1 \mathrm{mSv} / \mathrm{y}$ (단, 피부에 대한 둥가선량은 $50 \mathrm{mSv} / \mathrm{y}$ )를 적용 하고, 이에 근거하여 인공방사성핵종의 규제해제준위를 핵종 별 방사능농도 단위 $(\mathrm{Bq} / \mathrm{g})$ 로 유도하여 제시하였다. 천연방사 성핵종의 경우에는 규제배제(exclusion) 개념에 따라 국제연 합 과학위원회(United Nations Scientific Committee on the Effects of Atomic Radiation, UNSCEAR)가 제시한 전세계 토 양 내의 방사능농도 분포 상한치에 근거하여 뀨제해제준위를 $40 \mathrm{~K}$ 에 대해서 $10 \mathrm{~Bq} / \mathrm{g}$, 기타 천연방사성핵종에 대해서 1 $\mathrm{Bq} / \mathrm{g}$ 으로 제시하였다.

\section{나. 스웨덴}

스웨덴은 법적으로 방사성페기물을 종류별로 분류하고 있 지는 않으나, 처분방법에 따라 방사성폐기물의 범주를 사용 후핵연로(Spent Fuel, SF), 장수명 중 - 저준위폐기물(LILWLL), 단수명 중 - 저준위폐기물(LILW-SL) 및 극저준위폐기물 (VLLW)로 구분하여 관리하고 있다. 이 중에서 VLLW는 무제 한 규제해제, 규제기관의 결정에 따른 조건부 규제해제, 특수 연소로를 이용한 소각처리(페유에 한함) 둥의 방법으로 규제 해제하거나, 또는 원자력법에 따라 허가된 처분시설(SFR)에 처분하거나 VLLW 전용 처분시설에 처분할 수 있도록 허용되 고 있다[12].

현행 스웨덴의 규제요건에 따르면 VLLW의 무제한 규제해 제준위는 총방사능 $0.5 \mathrm{~Bq} / \mathrm{g}$ 이하(이중 알파선 방출핵종의 농도는 $0.1 \mathrm{~Bq} / \mathrm{g}$ 이하)이고, 페기물을 생활페기물 매립장에 매립할 경우에 적용되는 규제해제준위는 총방사능 $5 \mathrm{~Bq} / \mathrm{g}$ 이 하(이중 알파선 방출핵종의 농도는 $0.5 \mathrm{~Bq} / \mathrm{g}$ 이하)이며, 원전 의 방사선관리구역에서 반출될 수 있는 폐기물의 총방사능은 연간 $1 \mathrm{GBq}$ 이하로 졔한되고 있다. 한편, 폐유를 소각할 때 적용되는 규제해제기준은 베타선 및 감마선을 방출하는 핵종 의 경우 $5 \mathrm{~Bq} / \mathrm{g}$, 알마선을 방출하는 핵종의 경우 $0.1 \mathrm{~B} / \mathrm{g}$ 이 하로 규정되어 있다. 2004년을 기준으로 연간 약 600 톤의 VLLW가 생활폐기물 매립장예 매립되었고, 방사능농도가 0.5 $\mathrm{B} / \mathrm{qg}$ 미만인 고철 약 500 톤이 규제해제 제도를 통해 재활용 
되었다. 한편, 2011년부터 시행될 예정인 규제해제요건 개정 안에서는 무제한 재이용, 재활용 또는 처분할 경우에 대한 규 제해제기준으로 유럽연합의 권고보고서에 제시된 196개 핵 종에 대한 규제해제준위를 준용하고 있는 것으로 알려져 있 다[13].

스웨덴 규제기관은 아직까지 방사성폐기물 및 사웅후핵연 료 최종관리에 따른 규제요건(SSI FS 1998:1)의 적용범위에 VLLW를 포함하지 않고 있으나, 조만간 VLLW 전용 포충매립 형 처분시설에 대한 구체적인 규정을 개발할 예정이다. 이 규 정은 표층처분시설의 단기 및 장기 안전성에 영향을 미칠 수 있는 부지선정, 설계 및 운영 등과 관련된 안전현안에 적용될 예정이다.

현재 스웨덴은 발전용원자로 부지 3개소(Forsmark, Oskarshamns, Ringhals)와 원자력연구시설 부지 1개소 (Studsvik)에서 VLLW 전용 표층매립형 처분시설을 운영하고 있다. 이들 시설에 대한 주요 허가조건은 해당 처분시설로부 터 누출되는 방사성물질의 양이 현재 해당 부지에서 운영중 인 원자력시설에서 누출되는 양에 비해 미미한 수준이어야 한다는 것이다. VLLW 전용 표층매립형 처분시설 에서 법적으 로 허용될 수 있는 최대 처분가능 총방사능은 $10 \mathrm{TBq}$ 이하 (이 중 알파선 방출핵종의 총 방사능은 $10 \mathrm{GBq}$ 이하)이지만, 현재 운영중인 4 개소의 표층매립형 처분시설에 처분 가능한 총방사능은 100 1100 GBq의 낮은 수준으로 제한되고 있다. 초기에 허가된 표층매립형 처분시설은 반감기 5년 이상인 방 사성핵종의 농도를 $300 \mathrm{~Bq} / \mathrm{g}$ 이하로 제한하도록 허가조건이 부과되었으나, 최근 허가조건이 갱신된 Forsmark와 Ringhals 부지의 표층매립형 처분시설에서는 방사성핵종별 히옹농도 기준을 신규로 수립하여 적용하고 있는 추세이다. 일반적으 로 표층매립형 처분시설에서 처분작업은 매 3 5년 주기로 수행 되고, 처분작업이 수행되지 않는 기간 동안 해당 시설은 폐쇄된 상태로 유지되며, 폐기물을 처분할 때 마다 규제기관 의 승인을 받아야 한다.

운영중인 4 개소의 표층매립형 처분시설의 설계는 시설마다 다소 상이하지만, 처분시설의 상부에 밀봉층(sealing layer)을 설치하여 물의 침투를 방지하고, 폐쇄 시 최종적으로 $1 \mathrm{~m}$ 두 께의 토양 보호층을 조성하는 설계개념을 공통적으로 채택하 고 있다. 밀봉층의 재질은 벤토나이트 라이너(liner), 플라스 틱 막(membrane), 두꺼운 빙퇴석(calciferous moraine) 층 또는 이들을 혼합한 방식이 적용되고 있다. 초기에 조성 된 Forsmark 및 Studsvik 처분시설에는 처분고 하부에 천 연 · 반천연 지질학적 방벽을 설치하여 환경으로의 누출을 저감시키는 방식이 채택되었으나, Ringhals와 Oskarshamn
부지에서 최근 조성된 처분시설 에는 하류(down-gradient)에 외부 지질학적 방벽이 설치되었다. 모든 처분시설에서는 주 기적으로 침출수를 채춰하여 방사성핵종의 누설을 감시하고 있다.

3 개소의 원전 부지에 설치된 표층매립헝 처분시설에는 주 로 극저준위의 폐수지·배관 · 장비·절연재 · 방호복·폐 지·전선류 및 플라스틱 잡폐기물 등이 처분되고 있으며, 이 들 폐기물에 함유된 주요 방사성핵종은 ${ }^{60} \mathrm{Co},{ }^{137} \mathrm{Cs}$ 및 ${ }^{63} \mathrm{Ni}$ 등 이다. 한편, Studsvik 부지의 표층매립형 처분시설에는 동 연 구시설의 운영과정에서 발생된 폐기물과 노후 원자력시설의 해체과정에서 발생된 다양한 폐기물이 처분되고 있으며, 이 들 폐기물에 함유된 주요 방사성핵종은 ${ }^{60} \mathrm{Co},{ }^{137} \mathrm{Cs}, 3 \mathrm{H},{ }^{152} \mathrm{Eu}$ 및 ${ }^{154 \mathrm{Eu}}$ 등인 것으로 알려져 있다.

\section{(1) Forsmark 표충매립형 처분시설}

Forsmark 원전 부지의 표층매립형 처분시설은 빙퇴석 지 반 위의 지상에 조성되었으며, ${ }^{60} \mathrm{Co}$ 등 반감기 30 년 이하의 단수명 핵종을 주로 함유한 VLLW가 처분되고 있다. 처분대 상 폐기물에 함유된 단수명 핵종의 평균 방사능농도는 300 $\mathrm{Bq} / \mathrm{g}$ 미만, 포장물의 표면 방사선량률은 $0.5 \mathrm{mSv} / \mathrm{h}$ 미만, 처 분 총방사능은 $100 \mathrm{GBq}$ 미만으로 제한되고 있으며, 폐기물 은 200 리터 드럼, 압축드럼, 철재 박스, ISO 표준용기 등에 포장된 후 처분된다[14,15]. 그림 3은 Forsmark 부지의 VLLW 전용 표층매립형 처분시설의 개념도를 보여주고 있다[14,16].

처분시설의 하부에는 $3 \mathrm{~m}$ 두께의 빙퇴석이 타설되었고, 그 상부에 폐기물 포장물이 $4 \mathrm{~m}$ 두께로 정치되며, 폐기물 매립

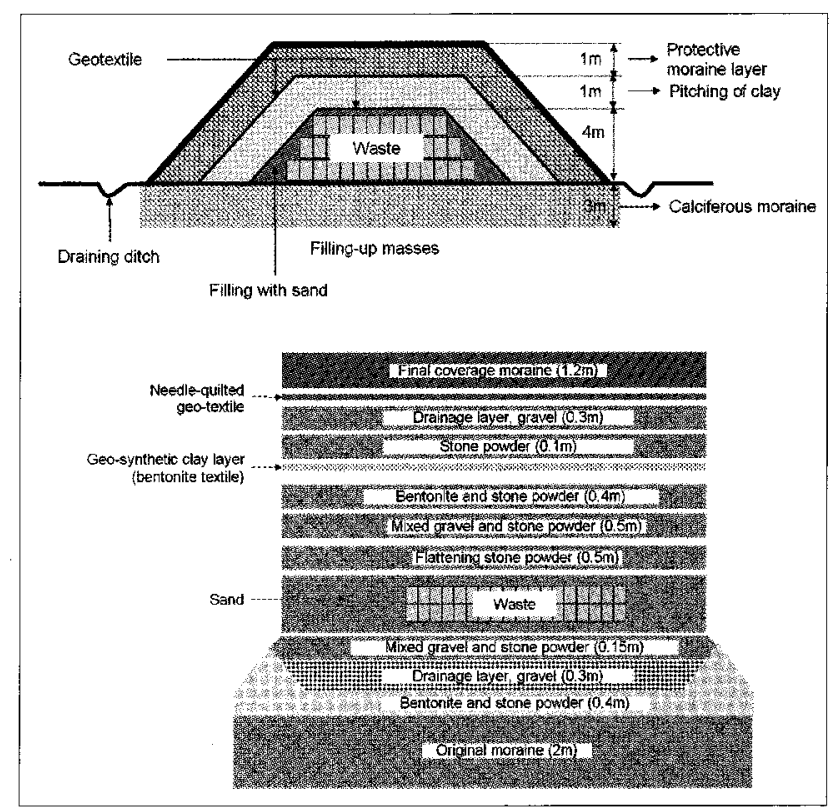

Fig. 3. Conceptual view of the VLLW disposal facility at Forsmark (FKA) in Sweden. 
층의 상부에는 $1 \mathrm{~m}$ 두께의 점토, 토목섬유(geo-textile) 및 1 $\mathrm{m}$ 두께의 빙퇴석 보호층이 시공되었다. 폐기물 포장물 사이 의 공간과 직상부에는 모래가 타설되었고, 보호층 상부에는 풀이 식재되어 있다. 이 시설은 외관상 대형 봉분과 유사한 형태를 갖추고 있으며, 처분작업을 수행할 때 기 조성된 봉분 의 측면을 절개하여 폐기물을 추가로 매립하고 있다.

한편, 바다로 유입되는 침출수의 오염여부를 감시하기 위 한 목적으로 다수의 감시정(monitoring well)을 설치하여 주 기적으로 시로를 채취한 후 시료의 방사능을 계측하고 있다. 지금까지 시설의 운영경험에 따르면, 처분시설의 운영에 따 라 바다로 유출되는 방사성물질의 수량은 원전에서 환경으로 배출되는 방사성물질의 수량에 비해 미미한 것으로 알려져 있다.

Forsmark 부지의 VLLW 전용 표층매립형 처분시설의 주요 특성정보를 부록 1 에, 이 시설에 처분할 수 있는 핵종별 방사 능농도 제한치를 부록 2에 요약하여 제시하였다.

\section{(2) Oskarshamns 표충매립형 처분시설}

Oskarshamns 원전 부지의 표층매립형 처분시설은 지표에 타설 된 콘크리트 패드 $(\mathrm{Pad})$ 위에 조성되었으며, 침출수는 처 분고 외부에 설치된 침투층으로 유입된 후 배수될 수 있도록 설계되었다. 규제기관의 허가조건에 따라 동 시설에 처분할 수 있는 총방사능은 $200 \mathrm{GBq}\left(\right.$ 이중 ${ }^{137} \mathrm{Cs}$ 은 $20 \mathrm{GBq}$ 까지 허 용)이다[12,14]. 그림 4는 Oskarshamns 부지의 VLLW 전용 표층매립형 처분시설의 개념도를 보여주고 있다[12].

Oskarshamns 부지의 VLLW 전용 표층매립형 처분시설의 주요 특성정보를 부록 1 에 요약하여 제시하였다.

\section{(3) Ringhals 표충매립형 처분시설}

Ringhals 원전 부지의 표층매립형 처분시설은 지표의 불투 수성 암반 표면 위에 설치되었으며, 침출수는 처분고 외부에 설치된 침투층으로 유입된 후 배수될 수 있도록 설계되었다.

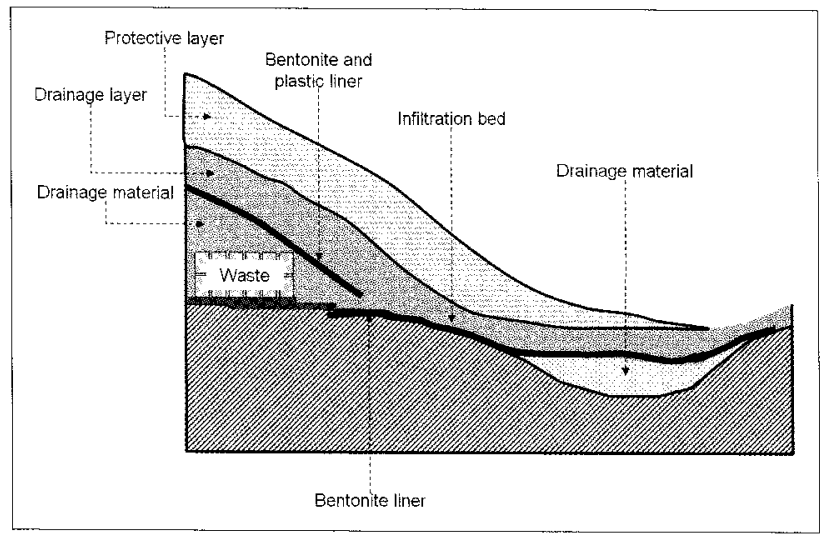

Fig. 4. Conceptual view of the VLLW disposal facility at Oskarshamns (OKG) in Sweden.
규제기관의 허가조건에 따라 이 시설에 처분할 수 있는 총방 사능은 $1100 \mathrm{GBq}$ 이며, 최대 $2 \mathrm{GBq}$ 의 ${ }^{90} \mathrm{Sr}, 900 \mathrm{GBq}$ 의 ${ }^{63 \mathrm{Ni}}$ 및 $100 \mathrm{GBq}$ 의 반감기 5 년 이상인 베타선 방출핵종 $(14 \mathrm{C}, 59 \mathrm{Ni}$, $36 \mathrm{Cl}$ )을 처분할 수 있다[12]. 이 시설에서는 지금까지 폐기물 매립작업이 총 3 회 수행되었다. 1993년 제 1 차 처분작업에서 는 $1,600 \mathrm{~m}$ 의 폐기물을, 1998 년 수행 된 제 2 차 처분작업에서 는 $1,800 \mathrm{~m}$ 의 폐기물을, 2008년 수행된 제3차 처분작업에서 는 $2,500 \mathrm{~m}^{3}$ 의 폐기물을 처분한 것으로 알려져 있다. 그림 5 는 Ringhals 부지의 VLLW 전용 표층매립형 처분시설의 개념 도롤 보여주고 있다[16].

Ringhals 부지의 VLLW 전용 표층매립형 처분시설의 주요 특성정보를 부록 1 에 요약하여 제시하였다.

\section{(4) Studsvik 표층매립형 처분시설}

Studsvik 연구시설 부지의 표층매립형 처분시설은 빙퇴석 지반의 지포면 이하에 건설되었으며 처분시설 상부의 밀봉층 은 지표면으로부터 $1 \mathrm{~m}$ 상부까지 돌출되어 있다. 우수의 배 수를 촉진하기 위하여 처분고 상부에 경사지게 시공된 덮개 층은 $0.5 \mathrm{~m}$ 두께의 점토층 위에 배수층, 빙퇴석 보호층 $(0.5$ $\mathrm{m}$ 두께) 및 토양을 이융하여 조성되었다[14]. 그림 6은 Studsvik 부지의 VLLW 전용 표층매립형 처분시설의 개념도 를 보여주고 있다[16].

Studsvik 부지의 VLLW 전용 표층매립형 처분시설의 주요

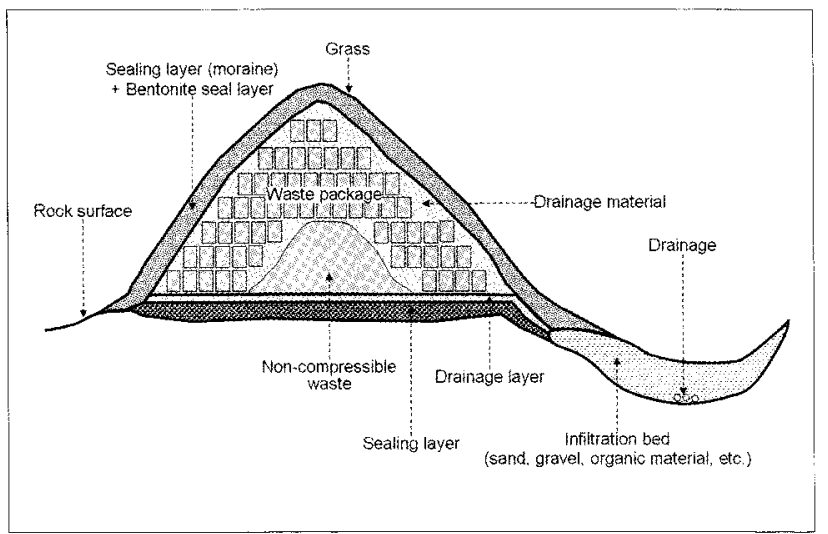

Fig. 5. Conceptual view of the VLLW disposal facility at Ringhals (RAB) in Sweden.

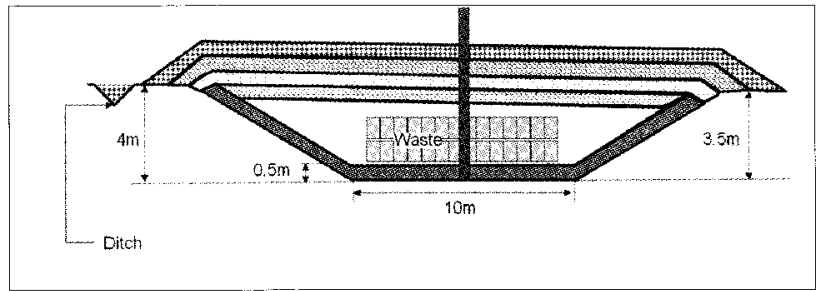

Fig. 6. Conceptual view of the VLLW disposal facility at Studsvik in Sweden. 
특성정보를 부록 1에 요약하여 제시하였다.

\section{다. 프랑스}

프랑스는 함유된 핵종의 방사능준위와 반감기에 따라 방 사성폐기물을 고준위폐기물(HLW), 장수명 중준위폐기물 (ILW-LL), 장수명 저준위폐기물(LLW-LL), 단수명 중 - 저준 위폐기물(LILW-SL), 극저준위폐기물(VLLW), 극단수명폐기 물(VSLW) 등 6개 범주로 분류하고 있다. 방사성폐기물에 대 한 규제해제 제도는 시행되지 않고 있으나, 구역화(zoning) 개념을 통해 원자력시설의 오염가능성이 있는 구역 내에서 발생된 폐기물은 모두 방사성폐기물로 관리하고, 오염가능 성이 없는 구역에서 발생된 폐기물은 비방사성폐기물로 구 분하여 관리하는 것이 원칙이다. 2007년 기준으로 VLLW는 방사성폐기물 총 저장량의 $20.1 \%$ (부피 기준) 또는 $0.000003 \%$ (방사능 기준)을 차지하고 있으며, 2020 년에는 $\mathrm{VLLW}$ 의 발생 - 저장량이 $580000 \mathrm{~m}$ 로 중가하여 방사성폐기 물 총 저장량의 $41 \%$ (부피 기준)를 차지할 것으로 예측되고 있다 $[6,17]$.

L'Aube 저준위폐기물 처분시설 인근에 VLLW 전용 표층매 립형 처분시설인 Morvilliers 처분시설을 건설하여 2003년부 터 VLLW를 처분하고 있다. Morvilliers 처분시설의 처분고는 수리전도도 $10^{-9} \mathrm{~m} / \mathrm{s}$ 미만의 백악기 점토층 지표면을 굴착하 여 조성되었으며, 각 처분고는 $80 \times 25 \mathrm{~m}$ 규격에 평균 심도는 약 $6.5 \mathrm{~m}$ 이다. 그림 7 은 Morvilliers 부지의 VLLW 전용 표층 매립형 처분시설의 개념도를 보여주고 있다.

운영중인 치분고의 상부예는 PVC(Poly Vinyl Chloride) 재 절의 아치형 철골 방수포(tarpaulin) 천막을 설치함으로써 우 수가 처분고로 침투되는 것을 방지한다. 폐기물을 정치하기 전에 처분고의 바닥과 측면에는 $2 \mathrm{~mm}$ 두께의 고밀도폴리에 틸렌(High Density PolyEthylene, HDPE) 재질의 토목용 막 (geo-membrane)을 설치한다. 처분고 내에서 폐기물 정치작 업이 완료되면 폐기물 메립층 상부에 동일한 재질의 토목용 막을 설치하고, 하부에 기 설치된 막과 상부에 설치된 막을

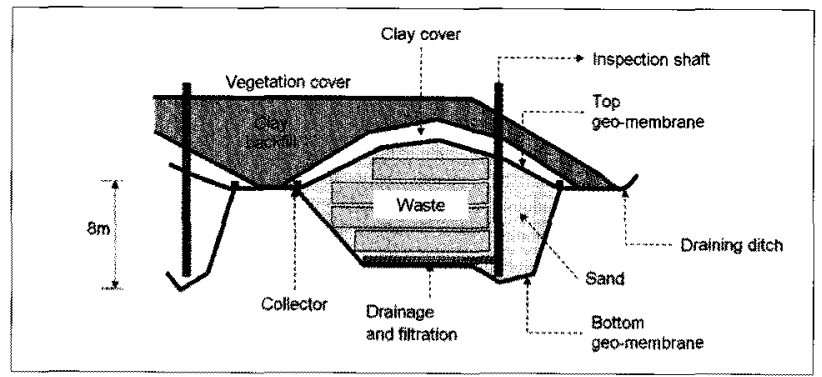

Fig. 7. Conceptual view of the VLLW disposal facility at Morvilliers (CSTFA) in France.
가열 - 접착함으로써 물이 폐기물 매립층 내부로 침투되는 것 을 방지한다. 이 시설에 적용된 토목용 막은 방수기능이 있으 며, 강수와 침투수에 의해 폐기물 내에 함유된 방사성물질이 외부로 침출 - 확산되는 것을 수십 년 동안 억제할 수 있도록 설계되었다. 처분고 바닥과 측면의 토목용 막 하부에는 점토 층이 $5 \mathrm{~m}$ 두께로 시공되어 저투수성 조건(수리전도도 $10^{-9}$ $\mathrm{m} / \mathrm{s}$ 미만)을 확보하고, 상부의 토목용 막 위에는 처분고를 굴 착하는 과정에서 발생된 점토질 물질을 1 5 $\mathrm{m}$ 두께로 시공 하며, 기계적인 압축을 통해 성형함으로써 초기의 저투수성 을 유지한다. 이후, 약 $2.5 \mathrm{~m}$ 두께의 점토질 뒤채움재를 상부 에 추가로 시공함으로써 퐁화작용, 침식 및 천공동물 (burrowing animals)에 의한 영향으로부터 처분고를 보호한 다. 마지막으로 전체 처분고 구조물 상부에는 $30 \mathrm{~cm}$ 두께의 영구적인 표토가 조성되고 그 위에 식물을 식재합으로써 폐 쇄작업이 완로된다. 각 처분고에는 감시정을 설치하여 비정 상 상황을 사전에 감시하고 있으며, 특히 감시정에서 물이 감 지될 경우에는 침출수를 양수하여 처리할 수 있도록 설계되 었다.

이 시설에 인수되는 폐기물의 약 $70 \%$ (비압축성 파쇄물 등) 는 처분고에 직접 처분되지만, 나머지 약 $30 \%$ 는 Morvilliers 부지내의 처리시설에서 추가적으로 처리한 후 처분되고 있 다. 저밀도 폐기물이나 경금속 폐기물은 압축기로 압축된 후 처분되며, 특정 산업페기물은 동 부지에서 고화시킨 후 처분 된다. 처분대상 폐기물의 포장물로서 저장용기, 대형 백(bag) 또는 금속재 랙(rack) 둥이 사용된다.

Morvilliers 처분시설에서는 IRAS(Radiological Index of Acceptance for Disposal)로 명명된 방사선학적 폐기물 인 수기준이 설정 및 적융되고 있다. 즉, $\mathrm{VLLW}$ 에 대한 비방사 능 제한치는 폐기물에 함유된 핵종의 방사성독성에 따라 4 개의 핵종군(group)별로 차등 적용되며, 다수의 방사성핵종 이 공존하는 페기물의 경우 아래에 정의된 IRAS가 인수된 한 배치(batch)의 폐기물에서 평균 “1" 이하, 폐기물 단일 포 장물에서 최대 " 10 " 이하가 될 수 있도록 제한되고 있다(표 1 참조),

$$
\operatorname{IRAS}=\sum_{i}^{N} \frac{A_{i}}{10^{C_{s}}}
$$

Table 1. Classes of radionuclides and their activity limits at Morvilliers VLLW disposal facility in France

\begin{tabular}{|c|c|c|c|}
\hline \multirow{2}{*}{ Class $\left(C_{i}\right)$} & \multirow{2}{*}{ Radionuclide } & \multicolumn{2}{|c|}{$\begin{array}{c}\text { Specific activity limit } \\
(\mathrm{Bq} / \mathrm{g})\end{array}$} \\
\hline & & Average & Maximum \\
\hline 0 & $=$ & 1 & 10 \\
\hline 1 & 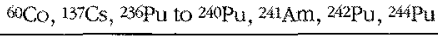 & 10 & 100 \\
\hline 2 & $232 \mathrm{U}$ to $238 \mathrm{U}$ & 100 & 1000 \\
\hline 3 & $3 \mathrm{H}, 14 \mathrm{C}, 63 \mathrm{M}, 90 \mathrm{Sr}$ & 1000 & 10000 \\
\hline
\end{tabular}


여기서, $\mathrm{N}=$ 폐기물에 함유된 방사성핵종의 개수, $\mathrm{A}_{\mathrm{i}}=$ 방사 성핵종 $\mathrm{i}$ 의 방사능농도 $(\mathrm{Bq} / \mathrm{g}), \mathrm{C}_{\mathrm{i}}=$ 방사성핵종 $\mathrm{i}$ 가 속한 핵종 군 $(0,1,2$ 또는 3$)$.

Morvilliers 부지의 VLLW 전용 표충매립형 처분시설의 주 요 특성정보를 부록 1 에, 이 시설에 처분할 수 있는 핵종별 방사능농도 제한치를 부록 2 에 오약하여 제시하였다.

\section{라. 스페인}

스페인은 방사성폐기물을 방사능준위에 따라 고준위폐기 물(HLW), 중 - 저준위폐기물(LILW), 극저준위폐기물(VLLW) 로 분류하고, LILW와 VLLW는 함유된 핵종의 반감기에 따라 장수명폐기물과 단수명폐기물로 세분하고 있으며, 원자력시 설 운영중 발생되는 폐기물의 $17 \%$, 해체폐기물의 $66 \%$ 가 VLLW에 해당하는 것으로 예상하고 있다[18]. VLLW에 대한 규제해제는 원전(Vandellós, José Cabrera) 및 연구시설의 해 체과정에서 발생된 폐기물에 대하여 사안별로 적용되고 있으 머, 규제해제준위로는 IAEA의 안전기준과 유럽연합의 권고 를 준용하고 있다[19].

스페인인 기존 $\mathrm{El} \mathrm{Cabril} \mathrm{중·저준위폐기물} \mathrm{처분시설} \mathrm{부지}$ 예 VLLW 전용 표층매립형 처분시설을 함께 조성하여 2008 년부터 운영하고 있다. 이 시설은 4 개 동(No. 29 -32)의 처분 셀(cell)로 구성되며, 현재 운영중인 제 1 처분셀의 처분용량 은 $33000 \mathrm{~m}$ 이고, 전체 처분셀의 용량은 $120000 \mathrm{~m}$ 이다. VLLW 처분시설에 처분될 수 있는 방사능은 El Cabril 부지 전체예 처분될 수 있는 방사능량의 $1 \%$ 를 초과하지 않도록 제한되고 있다. 그림 8은 El Cabril 부지의 VLLW 전용 표충매 립형 처분시설의 개념도를 보여주고 있다.

우선 처분셀의 하부에는 최소 $1 \mathrm{~m}$ 두께의 압축점토와 토목 용 벤토나이트(geo-bentonite) 필름을 설치함으로써 전체적 으로 수리전도도가 $10^{-9} \mathrm{~m} / \mathrm{s}$ 인 점도층 $5 \mathrm{~m}$ 에 상당하는 방사

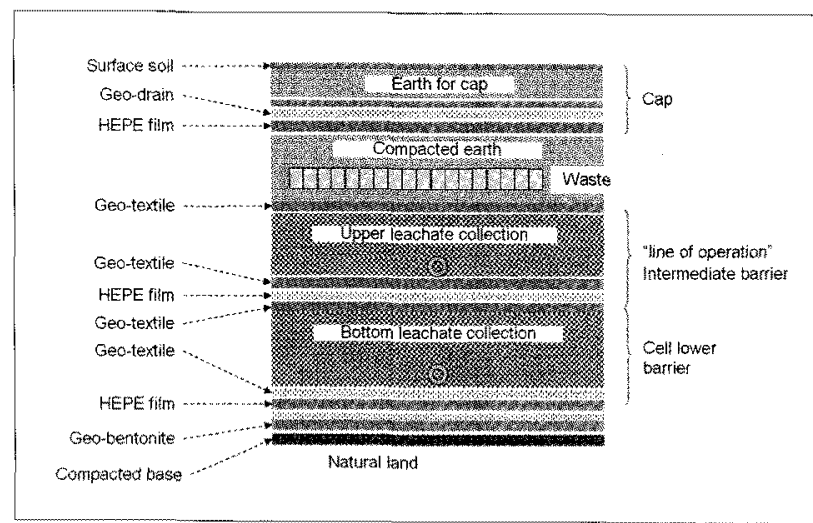

Fig. 8. Conceptual view of the VLLW disposal facility at El Cabril in Spain.
성핵종 지연성능을 확보하였고, 점토층 상부에는 HDPE 재질 의 방수용 필름을 설치하였으며, 방수용 필름 위에는 토목섬 유를 설치하였다. 각 처분셀 내에는 $4 \sim 6 \mathrm{~m}$ 두께의 독립적인 2 개의 폐기물 매립층이 다단계로 조성된다.

처분시스템의 점검 용이성을 제고하기 위하여 각 폐기물 매립층을 소위 다수의 운영구획(line of operation)으로 구분 하고 있으며, 각 운영구획은 다음 1-2년 동안 폐기물을 처분 할 수 있는 규모를 갖는다. 각 운영구획에는 HPDE 필름을 추 가로 설치하여 개별적으로 침출수를 수집할 수 있도록 시공 하였다. 처분작업이 수행중인 운영구획의 샹부에는 우수의 침투를 방지하고 침출수를 억제하기 위한 목적으로 경량 천 막이 설치되며, 특정 운영구획에서 예정된 수량의 패기물 처 분작업이 완로된 후에는 플라스틱 필름과 토층(earth layer) 으로 해당 구획을 임시로 폐쵀함으로써 방사성물질의 잠재적 인 유출 가능성을 최소화하고 있다.

한편, 각 처분셀 마다 독립적으로 배수수집계통이 설치되 어 폐기물과 접촉되었을 가능성이 있는 액쳬를 $100 \mathrm{~m}^{3}$ 용량 의 최종제어탱크로 이송할 수 있도록 설계되었다. 제 1 배수 수집계통은 자갈층 내에 설치된 $\mathrm{HDPE}$ 배관으로 각 처분셀 최하단부의 HDPE 필름 직상부에 설치되었으며, 제2 베수수 집계통은 처분셀 내의 개별 운영구획 내로 침투된 물을 수집 하는 집수관 네트워크로서 잠재적인 고장부위의 확인, 처분 시스템에 대한 감시 및 유지보수를 용이하계 하는 호과가 있 다. 이들 배수수집계통은 모두 HDPE 필름 상부의 자잘층 내 에 위치한다. 처분셀의 운영이 완료된 훙에는 다중의 공학적 점토충과 배수층이 설치되고, 폐쵀후 60년 동안 제도적관리 가 적용될 예정이다.

방사능농도가 정당화할 수 없이 희석된 폐기물은 동 처분 시설에 인수될 수 없으며, 폐기물 포장물의 선량룰은 2 $\mathrm{mSv} / \mathrm{h}$ 이하로, 제거성 포면오염도는 $0.4 \mathrm{~Bq} / \mathrm{cm}^{2}$ (알파선 방출 핵종) 또는 $4 \mathrm{~Bq} / \mathrm{cm}$ (에타 - 감마선 방출핵종) 이하로 제한된 다. 한편, El Cabril 표층매립형 치분시설의 인수기준은 프랑 스 Morvillers 처분시설과 유사하다. 즉, 각 처분 포장물군과 처분고에 대한 인수지수(Acceptance Index, AI)를 각각 아래 와 같이 정의하고, 처분 포장물군의 인수지수(AIDU)는 " 10 " 이하, 처불고의 인수지수(AIBatch)는 " 1 " 이하로 제한하고 있다.

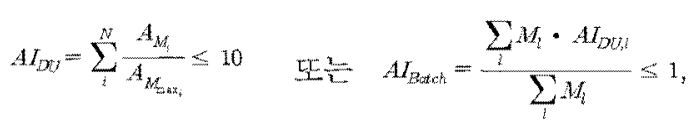

여기서, $\mathrm{A}_{\mathrm{Mi}}=$ 폐기물 내 방사성핵종 $\mathrm{i}$ 의 방사능농도 $(\mathrm{Bq} / \mathrm{g})$, $\mathrm{A}_{\mathrm{M}, \operatorname{maxi}}=$ 방사성핵종 $\mathrm{i}$ 의 방사능농도 제한치 $(\mathrm{Bq} / \mathrm{g}), \mathrm{M}_{l}=$ 처 
분 포장물군 $l$ 의 질량 $(\mathrm{g})$.

El Cabril 부지의 VLLW 전용 표층매립형 처분시설의 주요 특성정보를 부록 1 에, 이 시설에 처분할 수 있는 핵종별 방사 능농도 제한치를 부록 2에 요약하여 제시하였다.

\section{마. 일본}

일본은 방사성폐기물을 방사능준위와 발생 시설별로 세분 화하고 있다. 우선 방사능준위에 따라 방사성폐기물을 고준 위폐기물(HLW), 저준위폐기물(LLW) 및 규제해제폐기물로 구분하고, $\mathrm{LLW}$ 는 발생 시설에 따라 발전용원자로 폐기물, 장 수명 - 저열발생 폐기물(또는 초우라늄 폐기물), 우라눔 폐기 불, 연구시설 등 발생 폐기물로 세분하였다. 한편, 원전에서 발생된 LLW는 방사화폐기물, 저준위폐기물, 극저준위폐기물 둥으로 세분화고 있다[20]. 2005년부터 방사선학적 위험도가 미미한 폐기물에 대한 규제해제 제도가 시행되고 있으며, 이 에 따라 2007년 Tokai 1호기의 해체폐기물 중 일부가 처음으 로 규제에서 해제되었다. 일본의 규제해제는 주로 재활용이 가능한 콘크리트와 금속 폐기물에 국한하여 허용되고 있으 며, 해당 물질이 발생된 원자력시설의 부지에서 차폐체 또는 벤치(bench) 등으로 재활용하는 형태로 시행되고 있다. 참고 로 일본은 $1100 \mathrm{MWe}$ 급 가압경수로형 원전 1기를 해체할 경 우 충 50만 톤의 폐기물 발생되며, 이중 48만 49만 톤은 비 방사성폐기물 또는 방사능준위가 극히 낮은 폐기물이 될 것 으로 예상하고 있다[99].

일본은 방사성폐기물의 위험도와 특성에 따라 처분심도를 차등화하는 접근방법을 채택하고 있다. 이에 따라 제 1 종 폐 기물로 명명된 $\mathrm{HLW}$ 는 지하심도 $300 \mathrm{~m}$ 이하의 심지층 처분 시설에 처분하고, 제2종 폐기물로 분류된 LLW 중 방사화폐 기물은 지하심도 $50 \sim 100 \mathrm{~m}$ 의 중간층처분, 기타 LLW는 천 층 피트(Pit) 처분, VLLW는 천층 트렌치(trench) 처분하는 것 이 원칙이다. 여기에서 천층 트렌치처분은 "공학적 포층매립 형 처분시설" 에 상당하는 것으로 볼 수 있다. 현재 운영중인 천층 트렌치 처분시설은 없으나, $90 \mathrm{MW} / \mathrm{h}$ 용량의 비능경수 로 실증로인 JPDR(Japan Power Demonstration Reactor)의 해체과정에서 발생된 콘크리트 폐기물을 1995년 Tokai 일본 원자력연구소(Japan Atomic Energy Agency, JAEA) 부지 내 의 천층 트렌치 처분시설에 처분한 사례가 있다[21].

Tokai 표층매립형 처분시설에서는 처분대상 콘크리트의 춰급을 용이하게 하고 분진의 생성을 방지하기 위하여 "유연 한 용기"라고 불리는 폴리에틸렌이나 폴리에스테르 재질의 백(bag)에 콘크리트 폐기물을 포장하여 처분하였으며, 이 포 장물의 외부 직경과 높이는 약 $1 \mathrm{~m}$ 이고 포장물당 용량은 약
$0.8 \mathrm{~m}$ 이다: 이 처분시설은 이미 폐쇄가 완료된 상테로 약 30 년 동안 제도적관리가 적용될 예정이다. 그림 9는 Tokai 부지 의 VLLW 표층매립형 처분시설의 개념도를 보여주고 있다.

Tokai 부지의 VLLW 전용 표층매립형 처분시설의 주요 특 성정보를 부록 1 에, 이 시설에 적용된 핵종별 방사능농도 상 한치를 부록 2 에 요약하여 제시하였다.

\section{바. 핀란드}

핀란드에서는 VLLW를 일반 규제해제 또는 사안별 규제해 제 제도를 통해 재이용 및 재활용하거나 또는 매립장에 처분 할 수 있도록 허용되고 있다. Olkiluoto 원전에서는 이러한 폐기물을 처분하기 위한 전용 매립장을 부지 내에 조성하여 운영하고 있으며, Loviisa 원전에서는 규제해제된 폐기물을 지역 매립장에 처분할 수 있도록 협약을 체졀하고 있다.

일반 규제해제의 경우, 대량의 물질에 대해서는 IAEA의 규 제해제 안전지침을 준용하고, 원자력시설 당 연간 100 톤 이 내 소량의 물질에 대해서는 알파선 방출핵종, 고에너지 베 타. 감마선 방출핵종 $\left({ }^{54} \mathrm{Mn},{ }^{58} \mathrm{Co},{ }^{60} \mathrm{Co},{ }^{65} \mathrm{Zn},{ }^{90} \mathrm{Sr},{ }^{106} \mathrm{Ru}\right.$, ${ }^{110 \mathrm{~m} A g},{ }^{124} \mathrm{Sb},{ }^{125} \mathrm{Sb},{ }^{134} \mathrm{Cs},{ }^{137} \mathrm{Cs},{ }^{144} \mathrm{Ce}$ 등) 및 저에너지 베 타 · 감마선 방출핵종 $\left(3 \mathrm{H},{ }^{14} \mathrm{C},{ }^{51} \mathrm{Cr},{ }^{55} \mathrm{Fe},{ }^{63} \mathrm{Ni}\right.$ 둥 $)$ 의 체적오염 규제해제준위를 각각 $0.1 \mathrm{~Bq} / \mathrm{g}, 1 \mathrm{~Bq} / \mathrm{g}$ 및 $10 \mathrm{~Bq} / \mathrm{g}$ 으로, 표 면오염 규제해제준위를 각각 $0.4 \mathrm{~Bq} / \mathrm{cm}^{2}, 4 \mathrm{~Bq} / \mathrm{cm}^{2}$ 및 $40 \mathrm{~Bq}$ $\mathrm{cm}^{2}$ 로 규정하고 있다[22]. 한편, 규제기관이 규제해제준위를 사안별로 승인하는 사안별 규제해제의 경우, 폐기물의 평균 방사능농도를 $10 \mathrm{~Bq} / \mathrm{g}$ 미만으로, 인수자가 소유하게 될 방사 능 총량을 $1 \mathrm{GBq}$ 미만(알파 방사능은 $10 \mathrm{MBq}$ 미만)으로 제 한하고 있다.

\section{사. 미국}

미국의 방사성폐기물 분류기준은 규제를 담당하는 연방정 부 부처에 따라 다소 차이가 있으나, 미국 원자력뀨제위원회 (Nuclear Regulatopry Commission, NRC)는 방사성폐기물을 고준위계기물(HLW)과 저준위폐기물(LLW)로 크게 구분하 고, LLW의 경우 그 방사능농도에 따라 A급(Class A), B급 (Class B) 및 $\mathrm{C}$ 급(Class)과 $\mathrm{C}$ 급 초과폐기물(Greater than

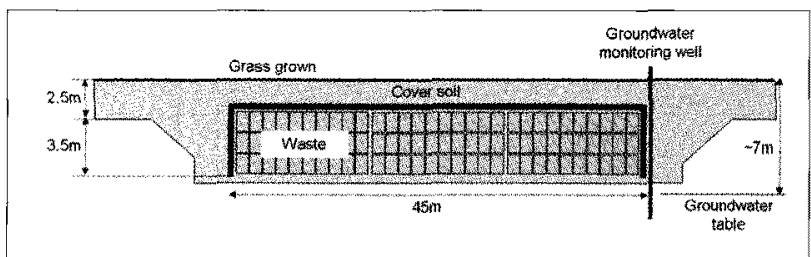

Fig. 9. Conceptual view of the VLLW disposal facility at Tokai in Japan. 
Class C, GTCC)로 세분하고 있다. VLLW가 법적인 방사성폐 기물의 범주로서 정의되어 있지는 않지만, US NRC는 저방사 능폐기물(Low-Activity Waste, LAW)이라는 용어를 관행적으 로 사용한다. 일반적으로 LAW는 유해폐기물 또는 생활폐기 물 매립장에서 안전하게 처분될 수 있는 소량의 잔류방사능 (천연방사성핵종 포함)을 함유한 폐기물을 의미한다.

$\mathrm{LAW}$ 는 미국 연방규정인 $10 \mathrm{CFR}$ Part 61 에 따라 허가된 LLW 처분시설에 처분할 수도 있으나, 그 오염도가 미미한 LAW는 10 CFR 20.2002(Method for Obtaining Approval of Proposed Disposal Procedures)에 따른 대체처분방법 (alternative disposal method)의 적용이 허용된다. 지금까지 승인된 대체 처분방법으로는 자원보존 - 복원법(Resource Conservation and Recovery Act, RCRA)에 따라 허가된 유해 폐기물 또는 생활폐기물 매립장에서의 처분이 대부분이지만, 원자력시설 부지 내부 또는 외부에 위치한 사유지에서의 처 분에도 적용될 수 있다. 지난 30 여 년 동안 $\mathrm{NRC}$ 에 접수된 10 CFR 20.2002에 따른 폐기물 대체처분 승인신청서 약 100건 이상 중에서 약 $2 / 3$ 은 원자력시설 부지내의 처분에 관한 것 이었으나, 최근에는 부지외 처분을 위한 승인신청이 다수를 차지하고 있는 것으로 알려져 있다(2000 2007년까지 20건 의 승인신청 중 17 건이 부지외 시설에서의 처분신청). US NRC는 $10 \mathrm{CFR} 20.2002$ 에 따른 대체처분방법을 통해 폐기물 을 처분시설까지 운반하는 거리를 크게 단축시킬 수 있고, 낮 은 처분비용으로 보다 더 다양한 처분방안을 고려할 수 있을 뿐 아니라, 공중의 건강 - 안전 및 환경을 보호할 수 있다는 입장을 제시하고 있다[23].

\section{아. 영국}

영국은 방사성폐기물을 방사능농도와 열발생률에 따라 고 준위폐기물(HLW), 중준위폐기물(ILW), 저준위폐기물(LLW) 및 극저준위폐기물(VLLW)로 분류하고 있으며, VLLW를 그 수량에 따라 추가적으로 세분하고 있다. 2007년 고체 LLW의 장기관리에 관한 정첵성명을 공표하면서, 기존의 LLW 중 상 당량이 극저준위의 방사성물질만을 함유하고 있다는 점과, 이들 폐기물에 의한 인간의 건강과 환경에 대한 리스크를 무 시할 만한 수준으로 제한하면서도 다양한 방법으로 처분할 수 있다는 점에 주목하였다. 이를 통해, LLW의 하위 범주로 서. VLLW에 대한 정의를 개정하고 대량의 VLLW도 폐기물 매 립장에 처분할 수 있도록 정책을 수정하였다[24].

소랑(low volume, LV)의 VLLW는 생활쓰레기나 산업패기 물과 함께 불특정 장소에 처분될 수 있는 폐기물로서, $0.1 \mathrm{~m}$ 당 총방사능이 $400 \mathrm{kBq}$ 미만이거나 또는 총방사능이 $40 \mathrm{kBq}$
미만인 단일 품목을 말한다(단, ${ }^{3} \mathrm{H}$ 와 ${ }^{14} \mathrm{C}$ 는 이 제한치의 10 배 까지 허용). 해당 폐기물이 발생된 원자력시설 부지 외부로 폐기물이 반출된 이후에는 처분에 대한 별도의 제한조건이 부과되지 않는다. 한편, 대량 (high volume, HV) VLLW는 특 정 매립장에 한정하여 처분될 수 있는 폐기물로서 총방사능 농도가 $4 \mathrm{MBq} / \operatorname{ton}(4 \mathrm{~Bq} / \mathrm{g})$ 이하인 페기물로 정의된다 $\left({ }^{3} \mathrm{H}\right.$ 는 이 제한치의 10 배까지 허용). 해당 폐기물이 발생된 원자력시 설 부지 외부로 폐기물이 반출된 이후에도 법적인 제한조건 이 부과된다는 점에서 소량의 VLLW와 차이가 있다.

1986년부터 Clifton Marsh 매립장에서 단수명 LLW와 VLLW가 처분되고 있으며, 2007년 VLLW 관리정책이 수정된 이후 규제기관인 Environmental Agency는 LLW 및 HVVLLW 매립장에 대한 3건의 허가신청(Augean South Ltd., Sita Ltd., Waste Recycling Ltd.)을 접수하여 심사를 수행중이 다.

\section{자. 기타}

최근 러시아를 포함한 구소련 일부 국가들은 스웨덴의 지 원 하에 VLLW 전용 표층매립형 처분시설 건설을 위한 타당 성 조사 또는 건설사업을 추진하고 있는 것으로 알려져 있다. 스웨덴은 국제지원사업의 일환으로 러시아 Andreeva Bay에 표층매립시설 건설을 위한 타당성 조사를 완료하고 매립시설 건설을 위한 상세설계 작업을 진행하고 있고, 리투아니아 Ignalina 원전부지에서 표층매립형 처분시설을 건설중이며, 슬로바키아에서도 포층매립형 처분시설의 건설을 고려중인 것으로 알려져 있다[25,26].

\section{III. 극저준위폐기물의 안전관리 특성분석}

\section{가. 극저준위폐기물의 분류체계}

미국, 스웨덴, 스폐인, 영국, 일본, 프랑스, 핀란드 등은 법 적으로 또는 실질적으로 VLLW를 방사성폐기물의 범주로서 분류하고 있으며, 이러한 VLLW를 기존의 LLW 처분방법과 차별화하여 전용 포층매립형 처분시설 또는 비원자력 유해 폐기물 매립장 등에 처분하고 있거나 처분할 계획이다. 최 근 VLLW를 별도의 방사성폐기물 범주로 구분하거나 VLLW 전용 표층매립형 처분시설의 건설을 고려하고 있는 국가들 이 점차 증가되고 있는 추세이며, 이들은 대부분 방사성폐 기물을 방사능농도와 반감기를 기준으로 세분하고, 각 폐기 물 범주별로 적합한 처분방안을 국가 방사성폐기물관리정 책 또는 관리계획에 명시하고 있다. 특히, 2010년 IAEA가 방사성폐기물 분류기준 개정을 통해 VLLW를 별도의 폐기 
물 범주로 구분하고 공학적 표층매립형 처분시설에서의 처 분을 대표적인 처분방법으로 권고함에 따라, 향후 리스크 차등접근법에 근거한 방사성폐기물의 분류체계와 장기관리 방안을 도입하는 사례는 더욱 확대될 것으로 예상된다.

국제적으로 VLLW를 별도의 방사성폐기물 범주로 정의하 거나 이에 대한 처분방안을 별도로 규정하는 사례가 증가되 고 있는 가장 큰 이유는, 특히 원자력시설의 해체과정에서 오염도가 미미한 VLLW가 대량으로 발생되며, 이러한 폐기 물에 대해서는 기존의 LILW 처분장에서 요구되는 수준에 비해 상대적으로 단순한 공학적방벽을 적용하더라도 방사 성핵종에 대한 장기적인 격리 및 지연성능을 달성할 수 있 음에 대한 공감대가 형성되고 있기 때문이라고 해석할 수 있다. 참고로, OECD/NEA는 VLLW를 별도의 방사성폐기물 범주로 구분하는 이유로서, 특정 국가에서 VLLW를 비원자 력 산업폐기물 매립장에 처분하는 것이 허용되지 않을 수 있고, 또한 LLW 처분장에 VLLW를 처분하는 것은 경제적으 로 불합리하거나 필요하지 않기 때문이라고 해석하고 있다 [6].

\section{나. 극저준위페기물의 규제해제와 처분의 연계성}

일부 국가에서는 VLLW 전용 표층매립형 처분을 규제해 제의 일환으로 간주하고 있으나 다른 국가들은 이들을 별도 의 개념으로 구분하여 시행하고 있는 등, VLLW의 규제해제 와 표층매립형 처분의 연계성은 국가별로 차이가 있는 것으 로 나타났다. 스웨덴과 영국은 규제해제준위를 다소 초과하 는 VLLW를 전용 처분시설에 처분하고 있으며, 규제해제 제 도를 도입하지 않은 프랑스는 원자력시설의 오염가능성이 있는 구역에서 발생된 폐기물 중에서 방사능농도가 낮은 VLLW를 전용 처분시설에 처분하고 있다. 스페인은 원자력 시설의 해체과정에서 발생된 폐기물에 대해서는 사안별 규 제해제를 허용하고 있으나, 이와 별도로 VLLW 전용 처분시 설을 운영하고 있다. 한편, 핀란드와 미국은 VLLW의 처분 을 규제해제의 일환으로 간주하는 대표적인 사례라고 할 수 있다.

즉, 규제해제 제도를 도입하지 않았거나 규제해제 제도와 VLLW 처분을 별도로 구분하여 적용하는 국가들은 자체적 인 또는 국제적인 규제해제준위를 다소 초과하는 VLLW를 전용 처분시설에 처분할 수 있도록 허용하고 있고, 전용 처 분시설에 처분할 수 있는 VLLW의 방사능준위는 유해폐기 물 또는 생활폐기물 매립시설에서 처분이 허용되는 방사능 준위 보다 상대적으로 높음을 알 수 있다. 한편, 모든 방사성 폐기물을 심지층처분시설에 처분할 예정인 독일과 네덜란
드는 VLLW를 별도의 방사성폐기물 범주로 정의하지 않고 있으며, 규제해제 제도를 통해 오염도가 미미한 VLLW의 관 리를 최적화할 예정인 것으로 파악되었다[27].

\section{다. 극저준위폐기물 처분시설의 종류 및 설계특성}

현재 국제적으로 VLLW의 처분이 허용되고 있는 시설은 (1)발생부지 내 VLLW 전용 처분시설, (2)중앙집중식 VLLW 전용 처분시설, (3)비원자력 유해폐기물 또는 생활폐기물 매 립시설 등으로 구분할 수 있다. 스웨덴(3개 원전부지 및 1 개 연구시설 부지), 핀란드(Forsmark 원전부지) 및 일본의 경 우에는 발생부지 내에 전용 처분시설을 운영하는 사례이다. 한편, 프랑스와 스페인은 중앙집중식 VLLW 전용 처분시설 을 운영하는 대표적인 사례로서, 기존의 LILW 처분시설 부 지 또는 인근에 VLLW 전용처분시설을 추가로 조성하였다 는 공통점이 있다. 한편, 유해폐기물 또는 생활폐기물 매립 시설 등에서 VLLW의 처분을 허용하는 사례는 영국, 미국, 스웨덴(규제해제 폐기물의 경우), 핀란드(Loviisa 원전 부지 의 경우) 등에서 찾아 볼 수 있다.

1980년대 후반 내지 1990년대 초반부터 VLLW 전용 처분 시설을 운영중인 스웨 덴을 제외하고, 2000년대 이후 프랑 스와 스페인이 VLLW 전용 처분시설을 건설· 운영하고 있 으며, 최근 영국이 VLLW 전용처분시설에 대한 인허가를 진 행 중임을 고려할 때, 향후 VLLW 전용 처분시설의 운영사 례는 점차 확대될 것으로 예상된다.

VLLW 전용 처분시설의 처분심도 및 공학적방벽의 설계 특성 등이 부분적으로 공개되어 있는 스웨덴, 프랑스, 스페 인 및 일본 등의 사례를 분석한 결과, 이들은 모두 "공학적 표층매립형 처분시설"로서 대부분 "지표면 \pm 수 $\mathrm{m}$ ” 지점 에 조성되었고, 콘크리트 등 기계적 안정성을 제공하는 공 학적방벽은 아니지만 대부분 유연성 있고 수십 년 동안 건 전성을 유지할 수 있는 다중의 방벽(토목막, 토목섬유, $\mathrm{HDPE}$ 필름, 파쇄석, 점토)을 채택하고 있다는 공통점이 있 다. 즉, VLLW 전용 표층매립형 처분시설의 설계는 프랑스, 일본, 스페인 등에서 운영중인 콘크리트 볼트(Vault)형 LILW 처분시설에 비해 방사성물질의 격리 및 지연성능은 상대적으로 떨어지지만 1960년대부터 미국에서 주로 운영 되고 있는 천층 트렌치(Trench)형 LILW 처분시설 보다는 개선된 설계특성을 갖는 것으로 볼 수 있다.

\section{IV. 시사점 및 결론}

방사성폐기물 안전관리 분야에서 많은 선도국들은 대부 
분 방사성폐기물을 방사능준위와 함유된 핵종의 반감기에 따라 세분화하고, 각 폐기물의 범주와 특성에 따라 적합한 장기 관리방안을 국가 방사성폐기부ㄹㅗㅗ 관리정책 또는 관리계 획에 구체적으로 수립하여 시행하고 있다. 국제원자력기구 와 다수의 선도국들은 방사성폐기물의 범주로서 극저준위 폐기물을 별도로 분류하고 있으며, 이들 폐기물은 국제적으 로 규제해제, 원자력산업계 내에서의 재활용, 전용 처분시 설 또는 비원자력 매립시설에서의 처분 둥의 방법으로 관리 되고 있다. 이러한 국제동향은 방사성폐기물의 분류, 장기 관리 방안의 수립 등에 있어서 이미 리스크 차등접근법이 광범위하게 적용되고 있음을 의미한다.

특히, 이미 중·저준위폐기물 처분장을 운영하고 있는 국 가들이, 부피 또는 질량 기준으로 방사성폐기물 재고량의 상당부분을 차지하는 극저준위폐기물을 위한 전용 처분시 설을 병행하여 건설 · 운영하거나 신규 도입을 고려하는 사 례가 점차 증가되고 있는 추세이다. 1980년대부터 운영되기 시작한 극저준위폐기물 전용 처분시설은 지난 20 년 이상의 운영경험을 통해 그 안전성이 입증된 것으로 볼 수 있으며, 이는 국제원자력기구가 극저준위폐기물에 대한 적절한 처 분방법으로 공학적 표층매립형 처분시설을 인정하고 있는 것과 맥락을 같이 한다. 그러나 극저준위폐기물 전용 처분 시설의 도입여부, 처분시설 부지의 위치, 처분할 수 있는 최 대 방사능 농도와 수량 등은 국가별로 상이하며, 이는 (1)규 제해제 제도의 도입여부와 적용범위, (2)비원자력 폐기물매 립장의 활용 가능성 및 사회수용성, (3)중 - 저준위폐기물 처 분시설의 가용성 등의 차이에 기인하는 것으로 분석되었다. 특히, 프랑스와 스페인이 규제해제 제도를 시행하지 않거나 매우 제한적으로 허용하면서 대용량의 중앙집중식 극저준 위폐기물 전용 처분시설(각각 200리터 용기 기준으로 325만 드럼 및 65만드럼 규모)을 운영하는 것은 규제해제에 대한 사회적 수용성을 고려한 접근방법으로 볼 수 있다.

아직까지 우리나라에서는 극저준위폐기물의 장기적인 관 리방안이 구체적으로 논의되지 못하고 있으나 이미 국내 원 자력시설에서도 규제해제준위 미만이거나 해외 전용 처분 시설에 처분 가능한 수준의 극저준위폐기물이 상당량 발생 되고 있으며, 앞으로 발전용원자로와 같은 대헝 원자력시설 의 해체가 본격적으로 착수되면 그 발생 - 저장량이 급증할 것이므로 향후 극저준위폐기물의 효과적인 관리대책이 잠 재적인 현안으로 대두될 가능성이 있다. 특히, 해체폐기물 은 시설 운영단계에 비해 비교적 단기간에 많은 양이 집중 적으로 발생되는 특성이 있으므로, 규제해제준위 미만의 모 든 폐기물을 규제해제하고 규제해제준위를 다소 초과하는
폐기물을 모두 중 - 저준위폐기물로 처분하는 것은 현실적 으로 불가능할 것으로 예상된다. 이와 관련하여, 국토면적 이 협소하고 인구밀집 지역이 많으며 방사성폐기물의 안전 관리에 대한 국민적 관심도가 높은 우리나라의 상황을 고려 할 때, 극저준위폐기물 중에서 재활용 - 재이용이 가능한 금 속폐기물은 원자력산업계 내에서 최대한 재활용 - 재이용하 고, 충분한 격리 및 격납기능이 확보된 극저준위폐기물 전 용 처분시설을 중앙집중식으로 조성하여 재활용 - 재이용이 불가능한 극저준위폐기물을 처분하는 방안을 관리대안의 하나로서 상정할 수 있을 것이다.

국내 극저준위폐기물에 대한 공식적인 관리대책은 앞으 로 종합적인 연구와 다양한 논의과정을 통해 수립 - 확정되 어야 하며, 국가 방사성폐기물 관리정책 및 관리계획의 틀 내에서 체계적으로 시행되어야 한다. 이러한 극저준위폐기 물 관리대책 수립과정에서 리스크 차등접근법은 다양한 대 안 중에서 최적화된 관리방안을 선정하는데 효과적으로 활 용될 수 있을 것이다. 한편, 극저준위폐기물 만을 독립적으 로 고려하여 관리방안을 모색하는 것 보다는 중 - 저준위폐 기물의 종합 관리계흭 등과 연계하여 향후 규제해제제도의 확장적용 가능성, 기술성, 사회수용성 및 경제성 등을 종합 적으로 고려함으로써 극저준위폐기물에 대한 국가 관리계 획을 단계별로 최적화하는 접근방법이 바람직할 것이다.

\section{감사의 글}

본 연구는 교육과학기술부가 시행한 원자력기술개발사업 의 일환으로 수행되었습니다.

\section{참고문헌}

[1] International Atomic Energy Agency, Fundamental Safety Principles, IAEA Safety Fundamentals No. SF-1, IAEA, Vienna (2006).

[2] National Council on Radiation Protection and Measurements, Risk-Based Classification of Radioactive Waste and Hazardous Chemical Wastes, NCRP Report No. 139 (2002).

[3] M. Dutzer, F. Chastagner, N. Ricquart and F. Duret, "Disposal of Very Low Level Waste and Safety Assessment," Proc. of an International Symposium - Disposal of Low Activity Radioactive Waste, pp. 153-162, December 13-17, 2004, 
Córdoba, Spain.

[4] 홍상범, 이봉재, 정운수, "연구로 1,2 호기 해체 철재폐 기물의 규제해제농도기준(안) 도출을 위한 연구," 방사 성폐기물학회지, 2(1), pp. 60-67 (2004).

[5] International Atomic Energy Agency, Classification of Radioactive Waste, IAEA Safety Standards Series No. GSG-1, IAEA, Vienna (2010).

[6] OECD/NEA, Nuclear Energy Outlook 2008, NEA, Paris (2009).

[7] 정재학, "극저준위 방사성폐기물의 방사성핵종 분포유 형에 기초하여 자체처분기준 만족여부를 판단하기 위한 통계학적 접근방법," 방사성폐기물학회지, 8(2), pp. 123-133 (2010).

[8] 정재학, "방사성폐기물 안전규제 현안 및 규제방향," 제 15 회 원자력안전기술정보회의, 2010.4.20, 롯데호텔, 서울.

[9] 이관희, "극저준위폐기물의 자체처분 규제경험 및 기술 현안," 제 15 회 원자력안전기술정보회의, 2010.4.20, 롯 데호텔, 서울.

[10] Commission of the European Communities, Inventory of Information for the Identification of Guiding Principles in the Decommissioning of Nuclear Installations, EUR-13642, CEC, Brussels (1991).

[11] International Atomic Energy Agency, Application of the Concepts of Exclusion, Exemption and Clearance, IAEA Safety Standards Series No. RSG-1.7, IAEA, Vienna (2004).

[12] Ministry of the Environment, Sweden's Third National Report under the Joint Convention on the Safety of Spent Fuel Management and on the Safety of Radioactive Waste Management, DS 2008:73, Stockholm, Sweden (2008).

[13] European Commission, Practical Use of the Concepts of Clearance and Exemption, Part 1 Guidance on General Clearance Levels for Practice, EC Radiation Protection Publications No. 122(2000).

[14] A. Wiebert, "Shallow Land Disposal in Sweden," at the Meeting between Korea Institute of Nuclear Safety and Swedish Radiation Protection Authority, February 13-15, 2006, KINS, Daejeon.

[15] International Atomic Energy Agency, Country
Waste Profile Report for Sweden - Reporting Year 2008, IAEA, Vienna (2010).

[16] D. Aronsson, "Shallow Land Repositories for Very Low Level Waste," at the 23rd Contact Expert Group Plenary Meeting, October 7-9, 2009, Rome, Italy.

[17] Nuclear Safety Authority, Third National Report on Compliance with the Joint Convention Obligations, Paris, France (2008).

[18] Nuclear Safety Council, Third Spanish National Report under the Joint Convention on the Safety of Spent Fuel Management and on the Safety of Radioactive Waste Management, Madrid, Spain (2008).

[19] Nuclear Energy Agency, Release of Radioactive Materials and Buildings from Regulatory Control, NEA No. 6403 (2008).

[20] Government of Japan, National Report of Japan for the Third Review Meeting of the Joint Convention on the Safety of Spent Fuel Management and on the Safety of Radioactive Waste Management, Tokyo, Japan (2008).

[21] 일본 방사선안전규제검토회, RI - 연구소 등 폐기물의 처분을 위한 노력과 천층처분시설의 사례, 제 6 회 점토 회 배포자료 6-3 (2003).

[22] Finnish Radiation and Nuclear Safety Authority, Clearance of Nuclear Waste and Decommissioned Nuclear Facilities, Guide YVL 8.2 (2008).

[23] United States Nuclear Regulatory Commission, Low-Level Waste Disposal Under 10 CFR 20.2002, http://www.nrc.gov/waste/llw-disposal/10cfr202002-info.html (2010.08.30).

[24] Department for Environment, Food and Rural Affairs, Policy for the Long Term Management of Solid Low Level Radioactive Waste in the United Kingdom, London, UK (2007).

[25] Swedish Radiation Safety Authority, Cooperation in Nuclear Waste Management, Radiation Protection, Emergency Preparedness, Reactor Safety and Nuclear Non-Proliferation with the Russian Federation, Ukraine, Armenia, Georgia and Belarus, SSM Report 2010:19 (2010). 
[26] Commission of the European Communities, Second Report on the Use of Financial Resources Earmarked for the Decommissioning of Nuclear Installations, Spent Fuel and Radioactive Waste, COM (2007)794 Final (2009).

[27] Commission of the European Communities, Sixth Situation Report - Radioactive Waste and Spent Fuel Management in the European Union, COM (2008)542 Final (2008).

Appendix 1. Overview of worldwide engineered surface landfill type facilities for disposing of very low level radioactive waste.

\begin{tabular}{|c|c|c|c|c|c|c|c|}
\hline Country & Facility & $\begin{array}{l}\text { Disposal } \\
\text { capacity }\end{array}$ & $\begin{array}{l}\text { Disposed } \\
\text { waste } \\
\text { volume } \\
\end{array}$ & Depth & Operation & Closure & Disposable waste \\
\hline France & $\begin{array}{l}\text { Morvilliers } \\
\text { (CSTFA) }\end{array}$ & $650000 \mathrm{~m}$ & $\begin{array}{c}89000 \mathrm{~m} \\
(2007)\end{array}$ & $0 \mathrm{~m}$ & $2003-$ & $(2030)$ & $\begin{array}{l}\text { - Very low level waste from decommissioning of nuclear } \\
\text { power plants and hom operation of other faclities } \\
\text { - Nominal average activity }\langle 10 \mathrm{Ba} / \mathrm{g}\end{array}$ \\
\hline Spain & $\begin{array}{l}\text { ElCalbril } \\
\text { (RBBA) }\end{array}$ & $130000 \mathrm{~m}$ & $\begin{array}{c}952.95 \mathrm{~m} \\
(2009)\end{array}$ & $10 \mathrm{~m}$ & $\begin{array}{l}2008 \\
(2038)\end{array}$ & $(2039)$ & $\begin{array}{l}\text { - Very low level waste from molear power plants and } \\
\text { oher facilities } \\
\text { - Nominal maximum activity }<100 \mathrm{Bg} / \mathrm{g}\end{array}$ \\
\hline Japan & Tokat & $2520 \mathrm{mi}$ & $\begin{array}{c}1670 \text { ton } \\
(2009)\end{array}$ & $2.5 \sim 6 \mathrm{~m}$ & $\begin{array}{c}1995 \\
\sim 1996\end{array}$ & 1996 & - Decommissioning concrete waste from research reactors \\
\hline \multirow{4}{*}{ Sweder. } & $\begin{array}{c}\begin{array}{c}\text { Forsmak } \\
(\mathrm{FKA})\end{array} \\
\end{array}$ & $17000 \mathrm{~m}^{2}$ & $\begin{array}{l}3929 \mathrm{ni} \\
(2007) \\
\end{array}$ & $\sim 0 \mathrm{~m}$ & $1989 \sim$ & $(2040)$ & \multirow{2}{*}{$\begin{array}{l}\text { - very low level waste from nuclear power plants } \\
\text { - Total activity }(200 \mathrm{OBq}(\text { alpha }(0.2) \\
\text { - Activity concentration }\langle 300 \mathrm{~Bq} / \mathrm{g} \\
\text { - Surface dose rate }(0.5 \mathrm{msv} / \mathrm{h}\end{array}$} \\
\hline & $\begin{array}{c}\text { Oskarsharmans } \\
\text { (OKG) }\end{array}$ & $10000 \mathrm{~m}^{\prime}$ & $\begin{array}{l}7346 \mathrm{~m} 2 \\
(2007)\end{array}$ & $\sim 0 \mathrm{~m}$ & $1987 \sim$ & $(2025)$ & \\
\hline & $\begin{array}{c}\text { Ringhals } \\
\text { (RAB) }\end{array}$ & $10000 \mathrm{~m}^{\circ}$ & $\begin{array}{l}3471 \mathrm{~m} \\
(2007)\end{array}$ & $-0 m$ & 1993 & (2030) & $\begin{array}{l}\text { - very low level waste from nuclear power plants } \\
\text { - Total activity }(1100 \mathrm{GBq}(\text { alfika }(0.1) \\
\text { - Activity concentuation }(300 \mathrm{Ba} / \mathrm{g} \\
\text { - suface dose rate }(0.5 \mathrm{mSv} / \mathrm{h}\end{array}$ \\
\hline & $\begin{array}{c}\text { Stuctsvik } \\
\text { (ABSVAFO) }\end{array}$ & $1540 \mathrm{~m}$ & $\begin{array}{l}1140 \mathrm{n} \\
(2007)\end{array}$ & $\sim 0 \mathrm{~m}$ & $1987 \sim$ & $(2010)$ & $\begin{array}{l}\text { - very low level waste from nuclear power plants } \\
\text { - Total activity }<100 \mathrm{GBq} \text { (alpha }<0.1) \\
\text { - Activity concentration ( } 300 \mathrm{Bo} / \mathrm{g} \\
\text { - Surface dose rate }<0.5 \mathrm{mSv} / \mathrm{h}\end{array}$ \\
\hline
\end{tabular}


Appendix 2. Radiological waste acceptance criteria at the engineered surface landfill type facilities for disposing of very low level radioactive waste: column identifiers $A, B$ and $C$ mean the average specific activity per disposal unit, the maximum specific activity per package, the maximum activity concentration, respectively.

\begin{tabular}{|c|c|c|c|c|c|c|c|c|c|}
\hline \multirow[b]{2}{*}{ Nuclide } & \multicolumn{3}{|c|}{ El Cabril, Spain } & \multicolumn{3}{|c|}{ Morvillers, France } & \multicolumn{2}{|c|}{ Forsmark, Sweden } & \multirow{2}{*}{$\frac{\text { Japan }}{\mathrm{C}(\mathrm{Bq} / \mathrm{g})}$} \\
\hline & $\mathrm{A}(\mathrm{Bq} / \mathrm{g})$ & $\mathrm{B}(\mathrm{Bq} / \mathrm{g})$ & $\begin{array}{c}\text { Total activity } \\
\text { (TBq) }\end{array}$ & $\mathrm{A}(\mathrm{Bq} / \mathrm{g})$ & $\mathrm{B}(\mathrm{B} q / \mathrm{g})$ & $\begin{array}{c}\text { Total activity } \\
\text { (TBq) }\end{array}$ & $\mathrm{B}(\mathrm{Bq} / \mathrm{g})$ & $\begin{array}{c}\text { Total activity } \\
\text { (TBq) }\end{array}$ & \\
\hline${ }^{3} \mathrm{H}$ & $1.0 \times 10^{3}$ & $1.0 \times 10^{4}$ & $2.0 \times 10^{\circ}$ & $1.0 \times 10^{3}$ & $1.0 \times 10^{4}$ & & $1.0 \times 10^{2}$ & $2.1 \times 10^{-4}$ & $1.1 \times 10^{\circ}$ \\
\hline${ }^{14} \mathrm{C}$ & $1.0 \times 10^{3}$ & $1.0 \times 10^{4}$ & $2.0 \times 10^{-1}$ & $1.0 \times 10^{3}$ & $1.0 \times 10^{4}$ & $1.9 \times 10^{0}$ & $1.0 \times 10^{1}$ & $1.6 \times 10^{-5}$ & $2.0 \times 10^{-2}$ \\
\hline${ }^{36} \mathrm{Cl}$ & & & & & & $6.4 \times 10^{-2}$ & & $1.3 \times 10^{-8}$ & $7.7 \times 10^{-5}$ \\
\hline${ }^{41} \mathrm{Ca}$ & & & & & & & & $8.2 \times 10^{-7}$ & $4.8 \times 10^{-3}$ \\
\hline${ }^{60} \mathrm{Co}$ & $1.0 \times 10^{1}$ & $1.0 \times 10^{2}$ & $2.0 \times 10^{2}$ & $1.0 \times 10^{1}$ & $1.0 \times 10^{2}$ & & $3.0 \times 10^{-1}$ & $9.8 \times 10^{-6}$ & $1.6 \times 10^{-1}$ \\
\hline${ }^{59} \mathrm{Ni}$ & & & $2.0 \times 10^{0}$ & & & & $1.0 \times 10^{2}$ & & \\
\hline${ }^{63} \mathrm{Ni}$ & $1.0 \times 10^{3}$ & $1.0 \times 10^{4}$ & $2.0 \times 10^{1}$ & $1.0 \times 10^{3}$ & $1.0 \times 10^{4}$ & & $1.0 \times 10^{2}$ & $2.4 \times 10^{-5}$ & $3.0 \times 10^{-2}$ \\
\hline${ }^{79} \mathrm{Se}$ & & & & & & $7.4 \times 10^{-1}$ & & & \\
\hline${ }^{90} \mathrm{Sr}$ & $1.0 \times 10^{3}$ & $1.0 \times 10^{4}$ & $2.0 \times 10^{1}$ & $1.0 \times 10^{3}$ & $1.0 \times 10^{4}$ & $3.7 \times 10^{1}$ & $1.0 \times 10^{0}$ & $1.6 \times 10^{-5}$ & $2.0 \times 10^{-2}$ \\
\hline${ }^{94} \mathrm{Nb}$ & & & $1.0 \times 10^{-2}$ & & & & $1.0 \times 10^{-1}$ & & \\
\hline${ }^{99} \mathrm{TC}$ & & & $3.2 \times 10^{-2}$ & & & $1.3 \times 10^{-1}$ & $1.0 \times 10^{0}$ & & \\
\hline${ }^{108 \mathrm{~m}_{\mathrm{Ag}}}$ & & & & & & $3.8 \times 10^{-3}$ & & & \\
\hline${ }^{126} \mathrm{Sn}$ & & & & & & $1.0 \times 10^{-1}$ & & & \\
\hline${ }^{129} \mathrm{~T}$ & & & $1.5 \times 10^{-3}$ & & & $3.1 \times 10^{-2}$ & $1.0 \times 10^{0}$ & & \\
\hline${ }^{135} \mathrm{Cs}$ & & & & & & $1.8 \times 10^{0}$ & & & \\
\hline${ }^{137} \mathrm{Cs}$ & $3.0 \times 10^{1}$ & $3.0 \times 10^{2}$ & $3.7 \times 10^{1}$ & $1.0 \times 10^{1}$ & $1.0 \times 10^{2}$ & & $3.0 \times 10^{0}$ & $2.4 \times 10^{-6}$ & $1.0 \times 10^{-2}$ \\
\hline${ }^{152} \mathrm{Eu}$ & & & & & & & & $1.9 \times 10^{-5}$ & $1.1 \times 10^{-1}$ \\
\hline${ }^{154} \mathrm{Eu}$ & & & & & & & & $8.6 \times 10^{-7}$ & $5.0 \times 10^{-3}$ \\
\hline${ }^{226} \mathrm{Ra}$ & & & & & & $1.4 \times 10^{0}$ & & & \\
\hline${ }^{232} \mathrm{Th}$ & & & & & & $1.2 \times 10^{-2}$ & & & \\
\hline${ }^{236} \mathrm{Pu}$ & & & & $1.0 \times 10^{1}$ & $1.0 \times 10^{2}$ & & & & \\
\hline${ }^{237} \mathrm{Pu}$ & & & & $1.0 \times 10^{1}$ & $1.0 \times 10^{2}$ & & & & \\
\hline${ }^{238} \mathrm{Pu}$ & & & & $1.0 \times 10^{1}$ & $1.0 \times 10^{2}$ & & $1.0 \times 10^{-1}$ & & \\
\hline${ }^{239} \mathrm{Pu}$ & & & & $1.0 \times 10^{1}$ & $1.0 \times 10^{2}$ & $1.2 \times 10^{0}$ & $1.0 \times 10^{-1}$ & & \\
\hline${ }^{240} \mathrm{Pu}$ & & & & $1.0 \times 10^{1}$ & $1.0 \times 10^{2}$ & & $1.0 \times 10^{-1}$ & & \\
\hline${ }^{241} \mathrm{Pu}$ & $1.0 \times 10^{3}$ & $1.0 \times 10^{4}$ & $1.2 \times 10^{0}$ & & & & $1.0 \times 10^{-1}$ & & \\
\hline${ }_{242} \mathrm{Pu}$ & & & & $1.0 \times 10^{1}$ & $1.0 \times 10^{2}$ & & & & \\
\hline${ }^{239,240} \mathrm{Pu}$ & $1.0 \times 10^{1}$ & $1.0 \times 10^{2}$ & & & & & & & \\
\hline${ }^{241} \mathrm{Am}$ & $1.0 \times 10^{1}$ & $1.0 \times 10^{2}$ & & $1.0 \times 10^{1}$ & $1.0 \times 10^{2}$ & & $1.0 \times 10^{-1}$ & & \\
\hline${ }^{244} \mathrm{Cm}$ & & & & & & & $1.0 \times 10^{0}$ & & \\
\hline${ }^{234} \mathrm{U} \sim{ }^{238} \mathrm{U}$ & $1.0 \times 10^{2}$ & $1.0 \times 10^{3}$ & & $1.0 \times 10^{2}$ & $1.0 \times 10^{3}$ & & & & \\
\hline Gross alpha & & & $2.7 \times 10^{-1}$ & & & & & $5.1 \times 10^{-7}$ & $6.4 \times 10^{-4}$ \\
\hline
\end{tabular}

